\title{
Correspondence
}

\section{Advancing Taxonomy in the Global South and completing the Grand Linnaean Enterprise}

\author{
K. D. PRATHAPAN ${ }^{1} \&$ PRIYADARSANAN DHARMA RAJAN ${ }^{2}$ \\ ${ }^{\prime}$ Department of Entomology, Kerala Agricultural University, Vellayani P.O., Trivandrum -695 522, Kerala, India, \\ "= prathapankd@gmail.com; ○ https://orcid.org/0000-0001-8493-1555 \\ ${ }^{2}$ Ashoka Trust for Research in Ecology and the Environment (ATREE), Bangalore 560064, India, \\ " priyan@atree.org; (1) https://orcid.org/0000-0001-8137-3404
}

Addressing the Linnaean short fall—lack of knowledge in taxonomy and phylogeny (Raven \& Wilson, 1992) - is a prerequisite for resolving the other six major knowledge gaps in understanding and conserving biodiversity such as Wallacean (species distribution), Prestonian (abundance), Darwinian (evolutionary patterns), Eltonian (species ecology), Raunkiaeran (behavior) and Hutchinsonian (species responses to habitat change) shortfalls (Hortal et al., 2015). Taxonomy - the capacity to identify and specify the elements of biodiversity - provides the core reference system and knowledge base upon which our understanding of biodiversity is based. Unambiguous identification of organisms is crucial for meeting development challenges of the $21^{\text {st }}$ century, particularly in developing countries. High quality taxonomic input is vital for poverty alleviation through sustainable agriculture, forestry, and fisheries, for combating insect pests and human diseases, disaster management, sustainable trade in biological products and management of alien invasive species. Inventories based on taxonomy provide baseline information for the assessment of changes as well as conservation and management of biodiversity.

The Convention on Biological Diversity (CBD), in its preamble, recognizes the general lack of information and knowledge regarding biological diversity, and the urgent need to develop scientific, technological and institutional capacities. Article 12 of the CBD takes into account the special needs of the developing countries for scientific and technical education and training for identification, conservation and sustainable use of biological diversity. Of the top 17 megadiverse countries, 15 (Brazil, China, Colombia, the Democratic Republic of the Congo, Ecuador, India, Indonesia, Madagascar, Malaysia, Mexico, Papua New Guinea, Peru, the Philippines, South Africa, and Venezuela) are denoted as 'developing' (or the Global South) by the United Nations, while two (the United States and Australia) are 'developed' (or the Global North). Deforestation and habitat loss are taking place at a faster rate in the developing world, where much of the biodiversity occurs (Hansen et al., 2013; FAO, 2018; Seymour \& Harris, 2019; Butler, 2019; Mongabay, 2019).

Biodiversity in the developing nations is dramatically being reduced due to the pressures of development and climate change, even before such diversity is recorded, catalogued or described. The tropical rainforests, covering no more than 7\% of the Earth's land surface, yet home to more than half of the world biota (Wilson, 1988), are being decimated at unprecedented pace, driving millions of species to extinction in the Global South. On the other side, biodiversity and taxonomic expertise are unevenly distributed, forging an inverse relationship to each other. It is estimated that nearly $80 \%$ of the taxonomists are based in North America and Europe, while only about $7 \%$ are from South America and Africa (Gaston \& May, 1992). Since the adoption of CBD in $1992,82 \%$ of the taxonomic publications and authors are from the developed countries, while developing countries' contribution, including the co-authored publications, is only $28 \%$, of which, taxonomists from the five BRICS nations-Brazil, Russia, India, China and South Africa - contributed more than 50\% (Tancoigne \& Ollivier, 2017). This mismatch between biodiversity and taxonomic expertise has been one of the major impediments in tackling the biodiversity crisis.

Taxonomy in the Global South is largely an unorganized enterprise, being undertaken on a minimal scale, mostly by a few passionate academics, with limited government support and public appreciation. Developing country taxonomists are also isolated from their counterparts in other countries, the global community of taxonomists, international taxonomic networks, and global centers of taxonomic research due to restrictions on exchange of biological material and even knowledge, consequent to the CBD inspired national laws. At the same time, access to natural habitats 
for collection and exploration is progressively being curtailed due to bureaucratic hurdles (Madhusudhan et $a l ., 2006)$. The current defunding of basic sciences and liberal arts, such as in Brazil (Andrade, 2019; Angelo, 2019) and India (since 1 April 2017, the Indian Council of Agricultural Research abruptly stopped funding the Network Project on Insect Biosystematics involving 11 institutions, which would have changed the contours of insect taxonomy in the country; ICAR, 2017), would further debilitate taxonomy in the South. Thus, the capacity of taxonomists in the South to respond to the needs of biodiversity conservation, such as (a) attaining the United Nations Sustainable Development Goals, the UN Strategy for Living in Harmony with Nature, and (b) the requirements of international agreements like the CBD, are being curtailed.

Disciplinary elitism and bias in favour of fashionable disciplines, evident in the university curricula, research funding as well as career opportunities, has pushed taxonomy to the bottom of academic ranking (Bhaskaran $\&$ Rajan, 2010). The erosion of taxonomic expertise has already taken the toll in the South, while it is necessary to blend classical taxonomy with modern techniques, such as DNA sequencing, to scale up characterization, cataloguing and description of biodiversity. For instance, global initiatives, such as the Earth BioGenome Project, cannot achieve the desired goals without strong foundations of taxonomy.

Though the current estimates suggest that there are likely to be at least 1 to 6 billion species on Earth (Larsen et al., 2017), the vast majority of them are yet to be identified, described or catalogued. Even amongst majority of the $1.8 \mathrm{~m}$ named species (Mora et al., 2011), other than their name, we know very little about their natural history or other biological attributes. Even in the case of well known, ecologically and economically important species, it is not uncommon to be wrongly identified or misclassified, resulting in deleterious consequences.

Quarter century has elapsed since the CBD was adopted by the nation states, however, very little has been achieved in overcoming the Linnaean short fall, as we missed the Aichi Targets (CBD, 2018; Leadley et.al., 2014) and other deadlines. Hence, there is an urgent need for equipping the biodiverse countries to meet the challenges. The Global Taxonomy Initiative (Secretariat of the Convention on Biological Diversity, 2008) of the $\mathrm{CBD}$, intended to address the taxonomic impediment (Environment Australia, 1998), so far could do very little to face this challenge.

Hence, we propose three most important measures for addressing the Linnaean shortfall in the Global South such as, a) completing the Grand Linnaean Enterprise; b) massification of taxonomy; and c) creating an enabling legal and regulatory milieu, which would be our best hold against the global biodiversity crisis.

\section{a) Completing the Grand Linnaean Enterprise}

Most taxa in the Global South, excluding the charismatic and larger ones, need all-out effort to complete the Linnaean enterprise of naming and description. Revisionary studies and cataloguing of important taxonomic groups should receive immediate attention. Bawa (2010) has outlined actions necessary for enhancing taxonomic expertise in India, which is equally relevant for most countries in the South. These include:

1. Developing outstanding institutions for taxonomy to usher in a new era of exploration and discovery. The existing institutions should be liberated from bureaucratic shackles, revamped and reformed to face the challenges. These centers should: a) facilitate the completion of inventories of the flora and fauna; b) offer basic systematic biology courses for undergraduate and graduate biology students; c) facilitate the use of information technology to organize and disseminate taxonomic data, and support biodiversity data portals to engage civil society in collating highly dispersed but immense biodiversity information; and d) develop tools including space and Artificial Intelligence technologies for aiding taxonomy.

2. Strengthening and creating centers of excellence in academic institutions, which will function as primary places of training of new taxonomists. Zoological museums and herbaria associated with these academic institutions should be transformed into knowledge power houses of biology.

3. Providing more academic opportunities and training of a new generation of taxonomists from the Global South, who are adept in modern principles and techniques in taxonomy.

4. A fellowship program, would allow these young taxonomists to spend one or two years at the world's foremost institutions, so that a highly competent and motivated cadre is created within a short period.

The success of the Green Revolution of the 1960s, that saved the world from starvation, through boosting food production in the developing countries, is worth emulating. In India, a network of agricultural research institutions was built up under the aegis of the Indian Council of Agricultural Research (ICAR) and a number of State Agricultural Universities were established and funded liberally. Many faculty members from these institutions were deputed to the western universities for acquiring research degrees. Such institutions formed the scientific and technological back bone of the Green Revolution in India and other developing countries. Through concerted action, akin to that made the Green Revolution happen, institutions, infrastructure and expertise can be created for taxonomy in the Global South.

\section{b) Massification of taxonomy}

Making it possible for anyone to identify any organism (Wilson, 1984) should be one of the ultimate goals of taxonomy. Taxonomy in the early years has developed through the dedicated service of amateurs and service personnel. However, taxonomy as a science lost its traction 
and failed to sustain attention of the general public except in the case of charismatic groups like butterflies. The rich and diverse biota of the South warrants a large workforce of professionals and amateurs, adequately funded and supported by the governments and the public, to complete the Grand Linnaean Enterprise. This can be achieved through popularization and democratization of taxonomy by involving and training communities, citizens, amateurs and students in a massive scale in explorations, naming and cataloguing of species (Bawa, 2010). In return, taxonomists should address the end users' concerns and requirements (Ebach et al., 2011) besides engaging the political leadership, governments and the civil society at large.

Cybertaxonomy should be used in a massive scale to overcome the taxonomic impediment and the North-South divide. As a global common, internet has revolutionized dissemination, storage and retrieval of biodiversity information, besides popularizing the science of taxonomy. As Favret (2014) has pointed out, it aims to mobilize taxonomy by linking expertise, specimens, data and products across time and space, thus dramatically increasing taxonomic output without compromising quality. Limited access to type specimens has been one of the major downers of taxonomic work, especially in the South. Publication of high-resolution images of type specimens (e-types) on the internet will provide universal access to the type specimens which have been deposited in museums around the world, and greatly enhance the rate of taxonomic output. Cyber platforms, such as the Orthoptera species file (Cigliano et al., 2019), and online communities, like iNaturalist (Seltzer, 2019), would allow real time collaborations across the globe. Integrated digital platforms such as the India Biodiversity Portal (Vattakaven et al., 2016), where amateurs and experts can easily interact to aggregate curated biodiversity data of various kinds such as species pages (authentic species level taxonomic information), distribution maps, temporal distribution and life history information should be popularised.

\section{c) Creating an enabling legal and regulatory milieu} The southern countries should end their self-imposed isolation from rest of the world, which is largely based on misplaced notions of biopiracy. The adage attributed to Anton Chekhov, "There is no national science, just as there is no national multiplication table; what is national is no longer science" is extremely relevant for taxonomy. Life on Earth, which has originated from a single ancestor, does not respect political boundaries. Hence the theory and practice of taxonomy is universal and necessitates exchange of specimens and knowledge across the globe. Serious taxonomic work, such as revisions and monographic studies, require international collaboration and cooperation among taxonomists and institutions as the type specimens of even closely allied species may be held in institutions in different continents. Accurate generic and species identifications necessitate study of specimens from across political boundaries (Prathapan et al., 2008).

The CBD inspired national legislations themselves form a formidable obstacle in the practice of taxonomy in the Global South. Biodiversity researchers from the South have raised these issues and called for remedial measures (Grajal, 1999; Prathapan et al., 2008; 2018). There should be appropriate responses to these concerns at national and international levels, to create an enabling legal and regulatory framework for taxonomy. Hence the governments of developing countries should take initiatives for the following:

a) Bonafide taxonomists in recognized Institutions should be allowed to freely exchange specimens on loan for scientific studies and return the same to the sender without any permit hurdles. Developed nations such as the United Kingdom, USA, and many other countries adopt this practice.

b) To facilitate unrestricted access, especially for taxonomic revisions, taxonomists should be allowed to deposit type specimens in various museums across the globe. This will protect the interest of the country of origin, and act as an insurance against loss of type specimens.

c) The CBD might add an explicit treaty to promote and facilitate biodiversity research and international collaboration. This treaty may address legal uncertainties in the governance of global research commons such as microbial culture collections held by the World Federation of Culture Collections, Digital Sequence Information published through the portals of International Nucleotide Sequence Database Collaboration (INSDC) such as GenBank or taxonomic type materials held in various museums all over the world (Prathapan et al., 2018).

\section{Epilogue}

Wheeler et al. (2012) presented a powerful general vision for description of 10 million species in less than 50 years. We share the optimism of Wheeler and colleagues that the Grand Linnaean Enterprise can be completed within the span of a human generation as the world strives to reverse climate change, conserve biodiversity and sustain the planet liveable for billions of humans. Bridging the North-South divide in taxonomy will help us to create many more scientists, institutions and infrastructure, all dedicated to taxonomy and conservation. Through NorthSouth collaboration, and optimally making use of the scientific and technological advancements, the Linnaean dream can be translated into reality. 


\section{Literature cited}

Andrade, R. de .O. (2019) Brazil's budget cuts threaten more than 80,000 science scholarships. Nature, 572, 575-576. https://doi.org/10.1038/d41586-019-02484-w

Angelo, C. (2019) Brazil's government freezes nearly half of its science spending. Nature, 568, 155-156. https://doi.org/10.1038/d41586-019-01079-9

Bawa, K.S. (2010) Cataloguing life in India: the taxonomic imperative. Current Science, 98 (2), 151-153.

Bhaskaran, A. \& Rajan, P.D. (2010) Advancing the science of taxonomy in India. Current Science, 99 (2), 157-158.

Butler, R.A. (2019) Tropical forests' lost decade: the $2010 \mathrm{~s}$. Available from: https://news.mongabay.com/2019/12/ tropical-forests-lost-decade-the-2010s/ (Accessed 18 December 2019).

CBD (2018) Aichi Biodiversity Targets. Available from: https:// www.cbd.int/sp/targets/ (Accessed 18 December 2019).

Cigliano, M.M., Braun, H., Eades, D.C. \& Otte. D. (2019) Orthoptera Species File. Version 5.0/5.0. Available from: http://orthoptera.speciesfile.org/HomePage/Orthoptera/ HomePage.aspx (Accessed 18 December 2019).

Ebach, M.C., Valdecasas, A.G. \& Wheeler, Q.D. (2011) Impediments to taxonomy and users of taxonomy: accessibility and impact evaluation. Cladistics, 27(5), $550-557$.

https://doi.org/10.1111/j.1096-0031.2011.00348.x

Environment Australia (1998) The Darwin Declaration. Australian Biological Resources Study, Environment Australia, Canberra. Available from: https://www.cbd. int/doc/meetings/cop/cop-04/information/cop-04-inf-28en.pdf (Accessed 17 December 2019).

FAO (2018) The State of the World's Forests 2018 - Forest Pathways to sustainable development. Rome. $118 \mathrm{pp}$. Available from: http://www.fao.org/3/I9535EN/i9535en. pdf (Accessed 12 December 2019).

Favret, C. (2014) Cybertaxonomy to accomplish big things in aphid systematics. Insect Science, 21(3), 392-399. https://doi.org/10.1111/1744-7917.12088

Gaston, K.J. \& May, R.M. (1992) Taxonomy of taxonomists. Nature, 356, 281-282. https://doi.org/10.1038/356281a0

Grajal, A. (1999) Biodiversity and the nation state: regulating access to genetic resources limits biodiversity research in developing countries. Conservation Biology, 13, 6-10. https://doi.org/10.1046/j.1523-1739.1999.013001006.x

Hansen, M.C., Potapov, P.V., Moore, R., Hancher, M., Turubanova, S.A.A., Tyukavina, A., Thau, D., Stehman, S.V., Goetz, S.J., Loveland, T.R., Kommareddy, A., Egorov, A., Chini, L., Justice, C. O. \& Townshend, J.R.G. (2013) High-resolution global maps of 21 st-century forest cover change. Science, 342 (6160), 850-853. https://doi.org/10.1126/science. 1244693

Hortal, J., de Bello, F., Diniz-Filho, J.A.F., Lewinsohn, T.M., Lobo, J.M. \& Ladle, R.J. (2015) Seven shortfalls that beset large-scale knowledge of biodiversity. Annual Review of Ecology, Evolution, and Systematics, 46, 523-549. https://doi.org/10.1146/annurev-ecolsys-112414-054400

ICAR (2017) Non-allocation of 2017-18 budget in respect of Network Project on Insect Biosystematics scheme.
Letter F. No. 3-3[NPIB]/2016-17/1243-281 dated 7 March 2017. Available from: https://www.scribd.com/ document/440710113/ICAR-Network-Project-on-InsectBiosystematics-Non-Allocation-of-2017-18-Budget (Accessed 24 December 2019).

Larsen, B.B., Miller, E.C., Rhodes, M.K. \& Wiens, J.J. (2017) Inordinate fondness multiplied and redistributed: the number of species on earth and the new pie of life. The Quarterly Review of Biology, 92(3), 229-265.

https://doi.org/10.1086/693564

Leadley, P.W., Krug, C.B., Alkemade, R., Pereira, H.M., Sumaila U.R., Walpole, M., Marques, A., Newbold, T., Teh, L.S.L, van Kolck, J., Bellard, C., JanuchowskiHartley, S.R. \& Mumby, P.J. (2014). Progress towards the Aichi Biodiversity Targets: An Assessment of Biodiversity Trends, Policy Scenarios and Key Actions. Secretariat of the Convention on Biological Diversity, Montreal, Canada, Technical Series 78, 500 pp. Available from: https://www. cbd.int/doc/publications/cbd-ts-78-en.pdf (Accessed 23 December 2019).

Madhusudhan, M.D., Shanker, K., Kumar, A., Mishra, C., Sinha, A., Arthur, R., Datta, A., Rangarajan, M., Chellam, R., Shahabuddin, G., Sankaran, R., Singh, M., Ramakrishnan, U. \& Rajan, P.D. (2006) Science in the wilderness: the predicament of scientific research in India's wildlife reserves. Current Science, 91(8), 1015-1019. Availiable from: https://www.currentscience.ac.in/Downloads/ article_id_091_08_1015_1019_0.pdf (Accessed 20 Jan. 2020)

Mongabay (2019) Deforestation figures for selected countries. Available from: https://rainforests.mongabay.com/ deforestation/ (Accessed 18 December 2019).

Mora, C., Tittensor, D.P., Adl, S., Simpson, A.G.B. \& Worm, B. (2011) How many species are there on earth and in the ocean?. PLoS Biology. 9 (8): e1001127. https://doi.org/10.1371/journal.pbio.1001127

Prathapan, K.D., Rajan, P.D., Narendran, T.C., Viraktamath, C.A., Aravind, N.A. \& Poorani, J. (2008) Death sentence on taxonomy in India. Current Science 94(2), 170-171.

Prathapan, K.D., Pethiyagoda, R., Bawa, K.S., Raven P.H., Rajan P.D., Acosta, L.E., Adams, B., Adl, S., Ahyong, S.T., Anderson, R., Arango, C.P., Arnedo, M.A., Armbruster, J.W., Avila, L.J., Azevedo, C.O., Baldo, D., Barclay, M.V.L., Baron-Szabo, R., Bauer, A.M., Bentlage, B., Bezdek, A., Bird, G., Blagoderov, V., Bocak, L., Bonaldo, A., Bond, J.E., Borkent, C.J., Branham, M.A., Carranza, S., Carreno, R., de Carvalho, M.R., Castroviejo-Fisher, S., Chiba, H., Ciampor, F., Clarke, D.J., Collins, A.G., Constantino, R., Crespo, F.A., Daly, M., Dominiak, P., Dronen, N., Dubois, A., Duda, T.F., Eleaume, M., Erlacher, S., Estrela, P.C., Evenhuis, N., Fehlauer-Ale, K.H., Fery, H., Fritz, U., Gaimari, S.D., Garrison, R., Gaubert, P., Geiger, D.L., Gill, A.C., Gimmel, M.L., Goldschmidt, T., Goswami, R., Gonzalez, A.P., Gonzalez, V.H., Gordon, D., Gower, D.J., Greenslade, P., Gusarov, V.I., Hajdu, E., Harms,D., Heinicke, M.P., Hilton, E.J., Hodgson, C.J., Hormiga, G., Hughes, L.E., Hutchings, P., Jager, P., Jennings, J.T., Kadej, M., Kaila, L., Kaminski, M.J., Karaman, G.S., Karanovic, T., Kathirithamby, J., Kerr, P.H., Kirkendall, L.R., Kitahara, M.V., Klautau, M., Kondratieff, B.C., 
Kroh, A., Labarque, F.M., Leavengood, J.M., Letardi, A., Liang, A.-P., Lima, F.C.T., Liu, Z., Lobl, I., Lohrmann, V., Malchus, N., Malipatil, M.B., Marques, A.C., MatzkeKarasz, R., Mayer, G., Mayoral, J.G., McInnes, S.J., Minelli, A., Moir, M.L., Monks, S., Morrone, J.J., Muster, C., Nagy, Z.T., Narayanan, K.S., Nearns, E.H., Nekola, J., Nihei, S.S., Nutzel, A., Ohler, A., Orrico, V.G.D., Padial, J.M., Page, L.M., Passos, P., Paulson, D., Perkins, P.D., Pfingstl, T., Prieto, C., Pinheiro, L.R., Pinto-daRocha, R., Prendini, L., Price, B., Prins, J.D., Ramirez, M., Rasmussen, C., Rasmussen, P., Redei, D., Ribera, I., Ricarte, A., Rivera, J., Rix, M.G., Rossaro, B., Roy, A.D., Ruiz, G.R.S., Salles, F.F., Sanborn, A.F., Sartori, M., Scholler, M., Schmelz, R.M., Schrodl, M., Segniagbeto, G.H., Serrano, J., Shimano, S., Shin, M.K., Sidorchuk, E., Siler, C.D., Sket, B., Smith, A.D., Smith, A.B.T., Smith, R., Smith-Pardo, A.H., Sparks, J., Sterrer, W.E., Stroinski, A., Svavarsson, J., Toledo, M., Twomey, E., Vasudevan, K., Vences, M., de Voogd, N., Wang, Q., Watson, G.W., Weiner, W.M., Weksler, M., Wesener, T., Whitmore, D., Wiklund, H., Williams, P.H., Winterton, S.L., Wood, T.S., Yen, S.-H., Zaher, H., Zhang, Z.-Q. \& Zhou, H.-Z. (2018) When the cure kills-CBD limits biodiversity research. Science, 360 (6396), 1405-1406.

https://doi.org/10.1126/science.aat9844.

Raven, P.H. \& Wilson, E.O. (1992) A fifty-year plan for biodiversity surveys. Science, 258 (5085), 1099-1100. https://doi.org/10.1126/science.258.5085.1099

Secretariat of the Convention on Biological Diversity (2008) Guide to the Global Taxonomy Initiative. CBD Technical Series. 30, 195 pp. Available from: https://www.cbd.int/ doc/publications/cbd-ts-30.pdf (Accessed 16 December 2019).

Seltzer, C. (2019) Making Biodiversity Data Social, Shareable, and Scalable: Reflections on iNaturalist \& citizen science. Biodiversity Information Science and Standards 3: e46670. https://doi.org/10.3897/biss.3.46670
Seymour, F. \& Harris, N.L. (2019) Reducing tropical deforestation. Science, 365 (6455), 756- 757.

https://doi.org/10.1126/science.aax 8546

Tancoigne, E. \& Ollivier, G. (2017) Evaluating the progress and needs of taxonomy since the Convention on Biological Diversity: going beyond the rate of species description. Australian Systematic Botany, 30 (4), 326-336. https://doi.org/10.1071/SB16017

Vattakaven, T., George, R.M., Balasubramanian D., RéjouMéchain, M., Muthusankar G., Ramesh, B.R. \& Prabhakar, R. (2016) India Biodiversity Portal: An integrated, interactive and participatory biodiversity informatics platform. Biodiversity Data Journal, 4, e10279. https://doi.org/10.3897/BDJ.4.e10279.

Wheeler, Q.D., Knapp, S., Stevenson, D.W., Stevenson, J., Blum, S.D., Boom, B.M., Borisy, G.G., Buizer, J.L., De Carvalho, M.R., Cibrian, A., Donoghue, M.J., Doyle, V., Gerson, E.M., Graham, C.H., Graves, P., Graves, S.J., Guralnick, R.P., Hamilton, A.L., Hanken, J., Law, W., Lipscomb, D.L., Lovejoy, T.E., Miller, H., Miller, J.S., Naeem, S., Novacek, M.J., Page, L.M., Platnick, N.I., Porter-Morgan, H., Raven, P.H., Solis, M.A., Valdecasas, A.G., Van Der Leeuw, S., Vasco, A., Vermeulen, N., Vogel, J., Walls, R.L., Wilson, E.O. \& Woolley, J.B. (2012) Mapping the biosphere: exploring species to understand the origin, organization and sustainability of biodiversity. Systematics and Biodiversity, 10 (1), 1-20. https://doi.org/10.1080/14772000.2012.665095

Wilson, E.O. (1984) Biophilia. Harvard University Press, Cambridge, MA, 168 pp.

Wilson, E.O. (1988) The current state of biological diversity. In: Wilson, E.O. \& Peter, M.F. (Eds.) Biodiversity. National Academy Press, Washington, D.C., pp. 3-18. Available from: https://www.nap.edu/read/989/chapter/2\#3 (Accessed 20 Jan. 2020). 